\title{
Reviewer Acknowledgements for Global Journal of Health Science, Vol. 11, No. 3
}

Global Journal of Health Science wishes to acknowledge the following individuals for their assistance with peer review of manuscripts for this issue. Their help and contributions in maintaining the quality of the journal are greatly appreciated.

Global Journal of Health Science is recruiting reviewers for the journal. If you are interested in becoming a reviewer, we welcome you to join us. Please find the application form and details at http://recruitment.ccsenet.org and e-mail the completed application form to gjhs@ccsenet.org.

\section{Reviewers for Volume 11, Number 3}

Abdulbari Bener, Istaanbul University, Turkey

Ama Pokuaa Fenny, University of Ghana, Ghana

Amy E Jetton, Middle Tennessee State University Murfreesboro, United States of Ameri

António Calha, Polytechnic Institute of Portalegre, Portugal

Ayesha Johnson, University of South Florida, United States of America

Diadie Maiga, Management Sciences for Health in Arlington, United States of America

Dilek Pirim, Uludag University, Turkey

Domitila Augusta Huber, Federal University of Santa Catarina, Brazil

Farahnaz Amini, UCSI University, Malaysia

France Ncube, Bindura University of Science Education, Zimbabwe

Gabriel Gulis, University of Southern Denmark, Denmark

Gabriele Messina, University of Siena, Italy

Gavric Zivana, University Banja Luka, Bosnia and Herzegovina

Hülya YARDIMCI, Ankara University, Turkey

Loray Daws, British Columbia Masterson Institute, Canada

Marcel Wullschleger, University of Bern, Switzerland

Meng Zhao, Texas A\&M University at Corpus Christi, United States of America

Srikrishna Sulgodu Ramachandra, Public Health Foundation of India, India

Thanusin Saleeon, Ministry of Public Health, Thailand

Trisha Dunning, Deakin University and Barwon Health, Australia 